\title{
サブミクロン粒度測定グループ会の 測定結果の比較・検討
}

山 本 英 夫* Hideo YAMAMOTO

\section{1. はじめに}

粉体の諸特性に関与する最も基本的な因子は粒子の 大きさ(粒度)である。そのため, 今日まで種々の原理 に基づいた多種多様な測定装置が開発され，市販され てきた。特に最近では,レーザーやコンピュータ技 術，新しいセンサーなどの導入により，新原理の装置 化, 性能の向上, 測定の迅速化・簡便化は目覚まし い。試料を入れボタンを押すだけで自動的にデータが 再現性良く出てくる，簡便で迅速さを売り物にした八 イテク機器が続々登場し, 市販機種は50数種類にもの ぼる。

しかし，装置が進化したわりには粒度測定がかかえ る問題は一向に解決されていない。例えば，異なった 測定原理や方法による粒子径の測定結果を相互に比較 すると必ずしもよい一致がみられない。測定原理や機 種の多様化に伴ってその傾向はむしろ広がっているよ うに思われる。その大きな要因の一つは測定原理ごと に得られる粒子径の定義が異なることにある。実際に 測定される量は粒子の大きさに依存する物理量, 幾何 学量であって, 面積や体積であったり, 沈降速度や光 の散乱強度分布であったりする。これを，例えば球形 粒子に相当させて長さの次元の粒子径に換算している ので, 基本的には球形以外の粒子では一致しないのが 当然かも知れない。さらに, 原理間の整合性の悪さば かりでなく, 同じ原理の機種間, 同じ機種の装置間に も測定結果に差が見られるのも事実であり, ユーザー にとっては大きな問題となっている。したがって, 各 機種間の相互比較をし, その差異の原因を検討するこ とは重要な課題である。

1994年 12月 19 日受付

* 創価大学工学部( ₹192 八王子市丹木町 1-236)

TEL. $0462-91-9454$
粉体工学会では, 粉体工学研究会の時代からこの問 題の検討に繰り返し取り組んできた。特に1961年とい う早い時期に，第 1 回目の“粒度測定グループ会”が発 足し，共通試料を用いて，各種装置による共同測定が 行われた ${ }^{1}$ 。その後, 新しい原理の実用化, 新しい七 ンサーやコンピュータの導入により, 市販機種はさら に多様化した。そこで，1983年に第 2 回目の“粒度測 定グループ会”が発足し，7種の共通試料を用いた共同 測定により各種の原理，装置間の総合的比較検討がな され，多大な成果を上げた ${ }^{2)}$ ししし，ここで取り上 げられた共通試料は 1 種類を除いてすべてミクロンオ 一ダー以上の粒子であり，サブミクロン領域の測定に 関してはほとんど検討がなされなかった。ところが, 昨今の素材革命の急速な進展に伴い, サブミクロン以 下の粒子の箃密な粒子径評価の必要性が高まり, それ に対応する機種が統々と世に出されてきた。

そこで, 第 3 回目の粒度測定グループ会としでサ ブミクロン粒度測定グループ会”を発足させ, 1989年 から 4 年有余にわたって, 各種原理, 装置の詳細な検 討を行ってきた。活動はこれまでと同様に共通試料 (6 種）による共同測定を基幹とし, 各種測定原理の理論 的検討にまで踏み込んで機種間の整合性を検討した。 以下に, 4 年有余の活動の概要と, 得られた成果の一 部を紹介する。なお, 成果の詳細は, 「粒子径計測技 術」(粉体工学会編 ; 日刊工業新聞社発行) との題名の 成書にまとめて出版したので, 御一読いただければ幸 いである。

\section{2. 活動組織・内容, 参加機種}

グループ会には最終的に, 22 の大学・官公立研究 所, 15のユーザー会社, 14のメーカ・デイーラ会社か ら, 合計64名の方々の登録・参加を得た。

グループ会は幹事会, 小グループ会, 全体会議の 3 
表 1 小グループの(小G)の分類と参加機種

\begin{tabular}{|c|c|c|}
\hline 測定原理 & 小G世話人 & 参 加 機 種 \\
\hline 遠心沈降光透過法 & 鈴木和夫 (名工研) & $\begin{array}{l}\text { CAPA700(堀場), SKA5000, MPS-Z(七イシン), SA-CP4L, SA- } \\
\text { CP3(L), SA-CP2(島津), DCP-1000(日機装) }\end{array}$ \\
\hline X線透過法 & 遠藤茂寿(資環研) & $\begin{array}{l}\text { SediGraph5100(兼松), SediGraph5000D(島津) } \\
\text { BI-XDC (日機装) }\end{array}$ \\
\hline レーザー回折散乱法 & 高野頌(同志社大) & $\begin{array}{l}\text { LA-500, LA-700(堀場), SALAD-1100, SALD-2000(島津), SK- } \\
\text { PRO7000S, LMS-24(セイシン), HELOS(日本電子), HR-850(B) } \\
\text { (ニュ一メタルス・アンド・ケミカルズ), MasterSizer(日本ベル) } \\
\text { LS130(日科機), マイクロトラックSRA, SPA, FRA(日機装) }\end{array}$ \\
\hline 遮光法 & 伊ヶ崎文和(物質研) & CIS-1(セントラル科学貿易) \\
\hline 電気的㭘 & 山本节 & Multisizer(日科機)，パーティクルカウンター180XY(盟和商事) \\
\hline 光子相関法 & （国土舘大） & MALVERN(日本ベル) \\
\hline クロマトグラフィ法 & 森康維(同志社大) & 該当なし, 自作 \\
\hline 気相法 & 金岡千嘉男 (金沢大) & DMA, カスケードインパクター \\
\hline 遠心沈降重量法 & 横山豊和(ホソカワ) & アンバラン ス法, 差圧法 \\
\hline 画像解析法 & 遠藤茂寿(資環研) & ルーゼックス(ニレコ), LA555(ピアス), IP-1000(旭化成) \\
\hline
\end{tabular}

注 : 世話人の所属は現在のもの

つの組織で構成され，具体的な共同測定は小グループ 会が中心となって測定原理別に行った。したがって， 参加者は, 表 1 に示した10の測定原理別小グループに 分かれて活動した(重複参加可)。装置の測定原理・方 法を分類するに当たっては種々の考え方があるであろ うが，当グループ会では種々の観点から，便宜的に 10のグループに大別した。それぞれの特徴や留意点な どについては表 2 に示した。

小グループは小グループ世話人を中心に, 同じ測定 原理に属する市販機種の比較検討を行った。具体的に は表 1 に示した参加機種を用いて共通試料を共同測定 し，その結果を基にその測定原理の理論的，装置的問 題点, 機種間の整合性等を詳細に検討した。各小グル
一プには参加機種を開発・販売したメーカ・ディーラ に必ず参加してもらい, 装置のハード・ソフト両面の 特徵, 問題点, 留意点などに関する質疑に応答しても らった。また，測定にも参加してもらい，各社推奨の チャンピオンデータとユーザのデータとの比較も行 い, 機種ごとに測定上の問題点, 留意点等についても 検討した。

乾事会は各小グループの世話人と試料調製法担当者 によって構成され, 共通試料の選定, 各種粒子物性の 測定, 試料調製法の検討, 各小グループから報告され てきたデータおよび検討結果を基に各測定原理間の比 較検討などを行った。

全体会識は年 $2 \sim 3$ 回開催され，各小グループから

表 2 粒子径測定原理の分類と特徵

\begin{tabular}{|c|c|c|c|c|c|}
\hline \multicolumn{3}{|c|}{ 測 定 法 } & 粒子径の物理的意味 & 測 定 量 & 留 意 点 \\
\hline (1) & \multicolumn{2}{|c|}{ 遠心沈降光透過法 } & 流体抵抗径 & 透過光量 & 吸光係数, 粒子密度 \\
\hline (2) & \multicolumn{2}{|l|}{ X線透過法 } & 流体抵抗径 & 透過X線量 & 粒子密度, 愚濁液濃度 \\
\hline (3) & \multicolumn{2}{|c|}{ レーザー回折/散乱法 } & 光散乱相当径 & 回折/散乱パターン & 粒子屈折率 \\
\hline (4) & \multicolumn{2}{|l|}{ 遮光法 } & 幾何学径 & 遮光量 & 測定下限以下の粒子量 \\
\hline (5) & \multicolumn{2}{|l|}{ 電気的検知法 } & 幾何学径 & 電圧変動量 & 測定下限以下の粒子量 \\
\hline (6) & \multicolumn{2}{|l|}{ 光子相関法 } & 流体抵抗径 & 散乱光強度変動 & 分布幅の広い試料, ダイナミックレンジ \\
\hline \multirow{2}{*}{ (7) } & \multirow{2}{*}{$\begin{array}{l}\text { クロマトグラ } \\
\text { フィー法 }\end{array}$} & FFF法 & 流体抵抗径 & 透過光量 & 分解能の向上, 吸光係数 \\
\hline & & HDC法 & $?$ & 透過光量 & \\
\hline (8) & \multicolumn{2}{|l|}{ 気相法 } & & & 気相分離法, 迅速化 \\
\hline \multirow{2}{*}{ (9) } & \multirow{2}{*}{$\begin{array}{l}\text { 遠心沈降 } \\
\text { 重量法 }\end{array}$} & アンバランス法 & 流体抵抗径 & 重心移動量 & \\
\hline & & 差圧法 & 流体抵抗径 & 液中の圧力変動 & \\
\hline (10) & \multicolumn{2}{|l|}{ 画像解析法 } & 幾何学径 & 投影面積長さ & 標本 (画像)の作製, 計測個数 \\
\hline
\end{tabular}


の詳細な報告と幹事会からの総括的報告がなされ，そ れを基に更に詳細な検討が行われた。これにより, 多 くの問題点が抽出され, その内の幾つかは理論的, 技 術的に解決の系口が見いだされ, その後の共同測定に フィードバックされた。

共通試料の共同測定にあたって特に留意した点は, 測定試料の調製法であった。各測定原理, 装置に対し 適正な試料調製法があるのが当然であるが, 原理・機 種間の整合性を検討するために, 最低限度の共通条件 (次節参照)を設定した。各小グループはこの共通条件 に沿った測定と各々の原理・装置に最適と思われる条 件での測定の両方を実施した。

\section{3. 共通試料の物性と試料調製条件}

共通試料には, 研磨剂のWA\#10000とWA\#8000, 酸化鉄 $\left(\mathrm{Fe}_{2} \mathrm{O}_{3}: \alpha\right.$-ヘマタイト), 平均粒子径が約 0.5 , $0.9,1.4 \mu \mathrm{m} の 3$ 種の単分散シリカ粒子, 合計 6 種類を 用いた。図1〜6はそのSEM写真である。ご覧のよう に, 今回は比較的おとなしい形状の粒子を試料として 選定した。あまり複雑な形状の粒子であると, 各測定 原理に基づく差異よりも形状によるものが目立ってし まい, 本質的な整合性の議論ができなくなると考え た。また, 球形粒子であれば, どの原理による装置で 測定しても原則的には一致するはずであるので，も し, 共同測定結果に差が現れたときは, 各原理・装置

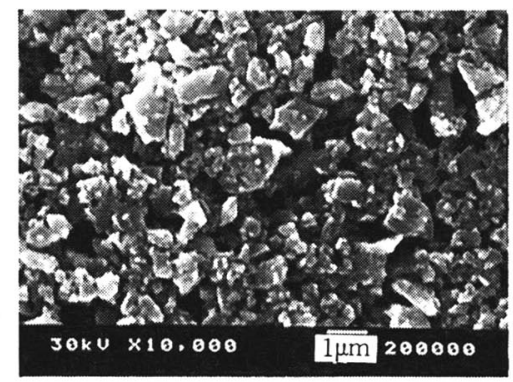

図 1 共通試料WA\#10000のSEM写真

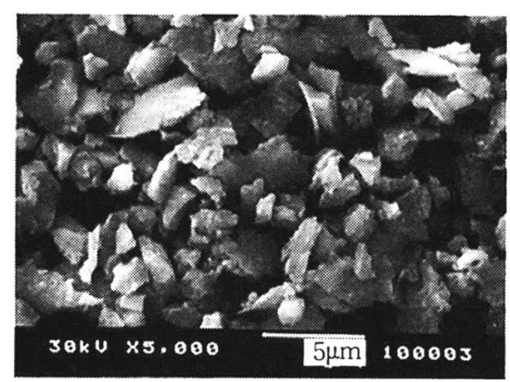

図 2 共通試料WA\#8000のSEM写真
の特性に迫ることのできる意味ある検討ができると期 待した。

粒子形状と観測粒子径の関係は大変興味深く重要な 問題であるが, 次期の粒度測定グループ会にゆだねる ことにした。（既に，第 4 回目の粒度測定グループ会

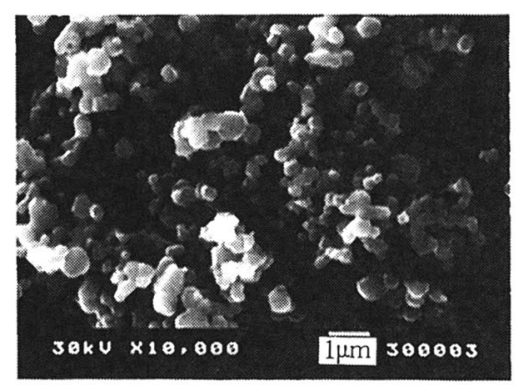

図 3 共通試料 $\mathrm{Fe}_{2} \mathrm{O}_{3}$ (酸化鉄: $\alpha$-ヘマタイト)のSEM写真

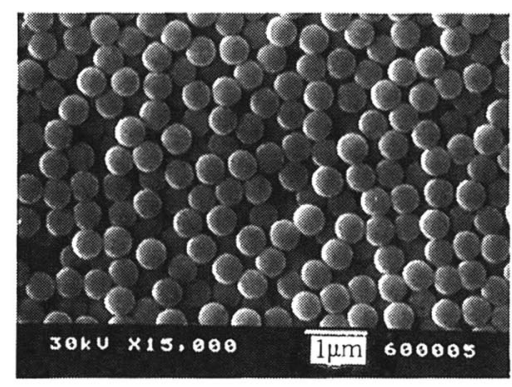

図 4 共通試料シリカ球形粒子(SP5H)のSEM写真

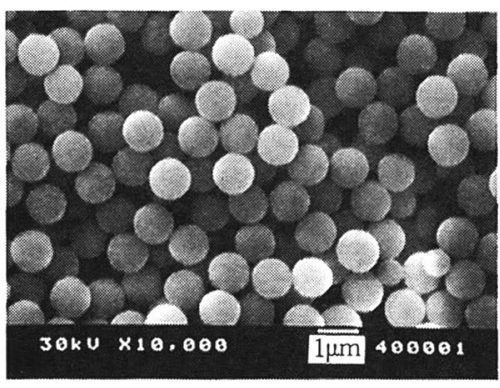

図 5 共通試料シリカ球形粒子(SP9H)のSEM写真

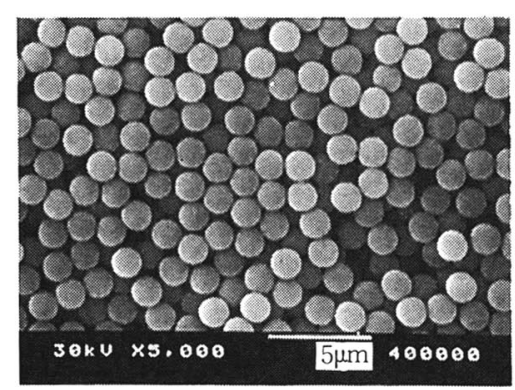

図 6 共通試料シリカ球形粒子(SP14H)のSEM写真 
が1994年11月にスタートした。代表世話人は資源環境 技術総合研究所の遠藤茂寿氏である。)

\section{1 試料の物性}

表 3 に各試料の粒子密度, 屈折率, 電位の実測値 を示した。各物性の測定条件は表に記したとおりであ る。共同測定に際しては共通条件としてこの物性值を 採用し，さらに，場合によっては各機種に最適と思わ れる物性值(例えば，届折率）を探索し，その值を用い た測定も実施した。

\section{2 試料の調製条件}

共同測定に際しては各試料の調製条件を以下のよう に統一した。

i) WA\# $10000, W A \# 8000$, 酸化鉄

分散媒: $0.05 \mathrm{wt} \%$ のへキサメタリン酸ナトリウム 水溶液

母液濃度：特に定めず，初めから各装置に最適な粒 子濃度にする。

分散条件：超音波バスで20分間分散させる。超音波 の出力は指定しない。

ii) $\mathrm{SP} 5 \mathrm{H}(0.5 \mu \mathrm{m}$ 球形シリカ粒子)

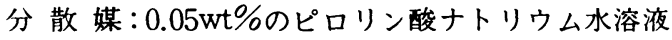

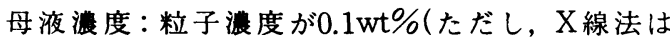
$5 \mathrm{wt} \%)$ ，測定時に各装置に最適な濃度に 希釈する。

分散条件: 300Wの超音波バスで15分間分散させる。 その際, 試料容器(ビーカ)は超音波バス の共振点に置く。

iii) $\mathrm{SP} 9 \mathrm{H}, \mathrm{SP} 14 \mathrm{H}(0.9,1.4 \mu \mathrm{m}$ 球形シリカ粒子)

分 散 媒: 0.025wt\%のピロリン酸ナトリウム水溶 液

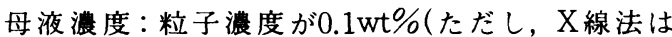
$5 \mathrm{wt} \%)$ ，測定時に各装置に最適な濃度に 希釈する。

分散条件：300～600Wの超音波バスで15分間分散さ せる。その際, 試料容器(ビーカ)は超音 波バスの共振点に置く。

試料調製条件i）を決定したのはグループ会がスター トしたばかりの頃で，試料の調製量，測定までの覆歴， 超音波の出力等がどの程度試料の分散状態に影響する のか詳細が不明であったので，このような，少々あい まいな条件設定となった。その後, グループ会の進行 とともに蓄積された情報により，母液の濃度と測定ま での経過処置・時間が微妙に影響することや，超音波 バスにおける最適分散操作点などの探索法などが明ら かになってきたので, シリカ粒子では少し厳密に条件 を規定した。これに関する情報も「粒子径計測技術」に 収録してある。

\section{4. 測定結果}

測定結果の比較検討方法には幾通りもの考え方があ るであろうが，本稿では基本的に次の考え方にしたが つて整理検討した。

1) 各試料ごとに，測定原理別に1枚の図にまとめ, 機種差, 装置差を比較検討する。

2) 各測定原理から得られる粒子径の意味は, 図7に 示したように,

a) 幾何学的特性による粒子径,

b) 動力学的特性による粒子径,

C) 光学的特性による粒子径

の3つに大別される。そこで, 電気的検知法・遮

表 3 共通試料の物性值

\begin{tabular}{|c|c|c|c|c|c|c|}
\hline & \multicolumn{2}{|c|}{ 研磨剂 } & \multirow{2}{*}{$\frac{\text { 酸化鉄 }}{\left(\mathrm{Fe}_{2} \mathrm{O}_{3}\right)}$} & \multicolumn{3}{|c|}{ 球形シリカ粒子 } \\
\hline & WA\# $\# 10000$ & WA\# 8000 & & $\begin{array}{c}\mathrm{SP} 5 \mathrm{H} \\
(0.5 \mu \mathrm{m})\end{array}$ & $\begin{array}{c}\text { SP9H } \\
(0.9 \mu \mathrm{m})\end{array}$ & $\begin{array}{l}\text { SP14H } \\
(1.4 \mu \mathrm{m})\end{array}$ \\
\hline $\begin{array}{c}\text { 粒子密度 }^{1)} \\
\left(\times 10^{3} \mathrm{~kg} / \mathrm{m}^{3}\right)\end{array}$ & 3.74 & 3.27 & 5.01 & 1.95 & 2.25 & 2.25 \\
\hline $\begin{array}{c}\text { 屈折率 }^{2)} \\
\text { 実数部のみ }\end{array}$ & 1.73 & 1.76 & $\begin{array}{c}2.4 \text { 以上 } \\
\text { (測定不能) }\end{array}$ & 1.44 & 1.45 & 1.45 \\
\hline $\begin{array}{c}\zeta \text { 電位 } \\
\end{array}$ & $-67.9^{a)}$ & $-80.2^{a)}$ & $-74.8^{\mathrm{a})}$ & $-89.9^{\mathrm{b})}$ & $-91.6^{c)}$ & $-95.0^{c)}$ \\
\hline
\end{tabular}

1）オートピクノメータ1320(Micromeritics社：空気置換法) 3 回測定した平均

2) RIMS(京都フィッショントラック社)で測定

3） PEN KEM社 MODEL501(電気泳動法)で測定

a) $0.05 w t \%$ $\%$ サメリン酸ナトリウム水溶液中

b） $0.05 \mathrm{wt} \%$ ピロリン酸ナトリウム水溶液中

c） $0.025 w t \%$ ピロリン酸ナトリウム水溶液中 


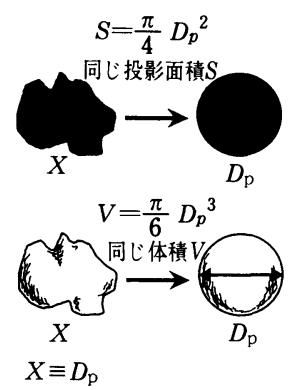

(a) 幾何学的特性

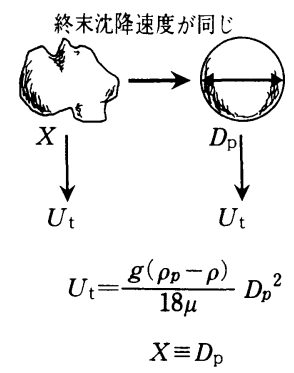

(b) 動力学的特性

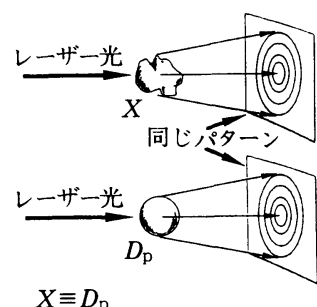

(c) 光学的特性

図 7 各測定原理によって観測される粒子径の意味

光法・画像解析法をa)グループ, 遠心沈降光透過 法・X線透過法・遠心沈降重量法をb) グループ, レーザ回折散乱法・光子相関法をc)グループとし て, 各々 1 枚の図にまとめて比較検討する。 読者各位には，独自の検討の仕方もおありであろう から，ここではデータの紹介を主たる目的とし，コメ ントは最小限にとどめる。他の考え方による比較につ いては，読者各自が必要なデータを図から読みとって 検討していただきたい。測定結果のグラフの縮尺等は すべて統一してあるので，コピーして重ね合わせれ ば，比較が容易にできるようになっている。

\section{1 WA $\# 10000$}

図 8 は幾何学的特性測定である遮光法(点線), 電気 的検知法 (実線)，画像解析法(一点鎖線)をまとめて表 示したものである。この場合の遮光法と電気的検知法 の測定下限はそれぞれ $0.4 ， 0.47 \mu \mathrm{m}$ であり，それ以下 の粒子は無いものとして解析しているので結果はかな り粗めにでている。したがって，参考データである。 一方, 画像解析法では計測個数が1000個以下なので, 大粒子をミスカウントしているものと思われる。しか し，2機種に差が見られるのは，サンプル画像の作製 法にも起因しているものと思われる。ちなみに，電子

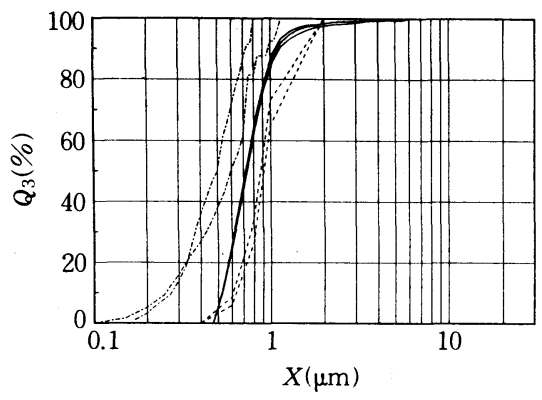

図 8 WA\#10000の電気的検知法 (実線), 遮光法 (点線), 画 像処理法(一点鎖線)による結果
顕微鏡から得られるサンプル画像にマークされている スケールは場合によっては数\%以上もの誤差があり， 違う電子顕微鏡で撮影したサンプル画像同士は場合に よっては $10 \%$ 近くの差になる可能性があることが判明 した。したがって,これ以後の画像解析法の比較検討 には同一の電子顕微鏡で撮影したネガから同一縮尺で 焼き増ししたサンプル画像を用いることにした。

図 9 は遠心沈降光透過法の 1 機種で，測定モードを 種々変えて測定した結果である。図には1000２000 $\mathrm{rpm}$ の定回転モードと120 960rpm / minの加速度モ 一ドで測定した結果が14本の曲線として示されている。 測定モードが違うと結果に若干の差異が現れるようで ある。しかし，この測定原理に起因する再現性の精度 からいうと比較的よく一致しているともいえる。

図10は同一メ一カーから市販されている遠心沈降光 透過法の 2 機種の比較である。実線が上位機種(後か ら市販されたもの)である。上位機種の結果は異なる $4 つ の$ 測定モード(3 加速モードと 1 定速モード)によ るものであり，かなりの差が認められる。一番右の実 線は定速モ一ドの結果であるが，他のモード(加速)に 比べてかなり粗めの結果となっており, 回転数が定速 に達するまでの立ち上がり期間の対流等による液の乱

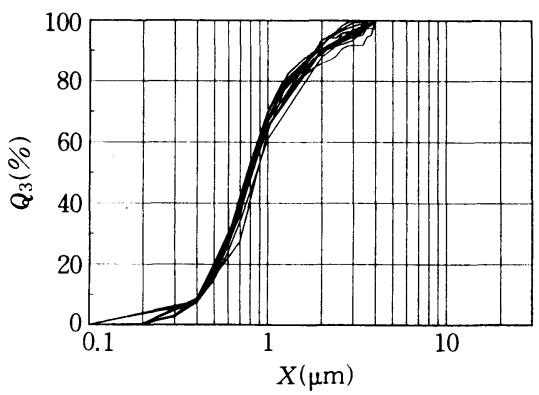

図 9 WA10000の遠心沈降光透過法による結果(1機種で異 なる測定モード） 


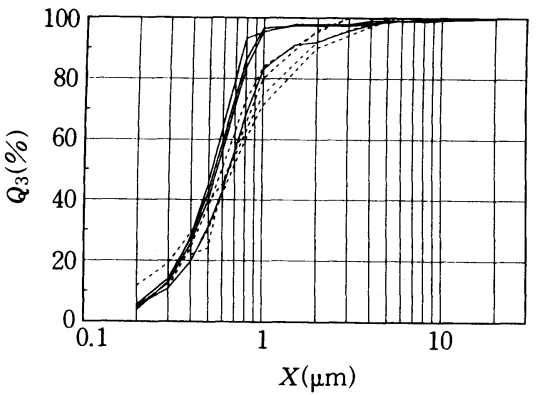

図 10 WA\#10000の遠心沈降光透過法による結果 (同一メ 一カの 2 機種)

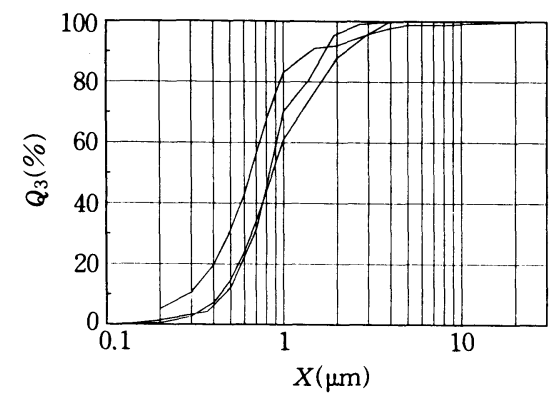

図 11 WA\#10000の遠心沈降光透過法による結果 $(x$ 一カ の異なる 3 機種)

れが気になった。一方，機種によっても結果に違いが 見られるが, 測定者, 測定場所が異なるので機種差が あるとは言い切れない。

図11は遠心沈降光透過法の3 機種(それぞれ異なる メーカ)のチャンピオン・デーダ1)を比較したもので ある。この試料はサブミクロン粒子を多く含むので, 主として各社の吸光係数の補正方法の違いが結果の差 として現れたのであろう。光透過法の弱点はサブミク ロンオーダーの粒子に対する吸光係数の補正が必要に なってくることであろう。これは粒子の大きさが可視 光の波長 $(0.38 \sim 0.78 \mu \mathrm{m})$ と同程度ないしそれ以下で あるためである。

図12はX線透過法2 機種による結果である。実線は 上位機種であり，異なる測定者(装置も異なる)による 6 本の結果が示してある。微粒側に若干の差異は見ら れるが再現性は極めて良いと言える。やはり，機種に よって, 若干の差が認められる。X線透過法は光透過 法のような吸光係数の補正を必要としないので, これ は, 装置構成, データ処理ソフトの両面の違いによる ものであろう。

*1）共通条件にこだわらず，装置を開発したメ一カがその装置 に最適とした条件で測定した結果。

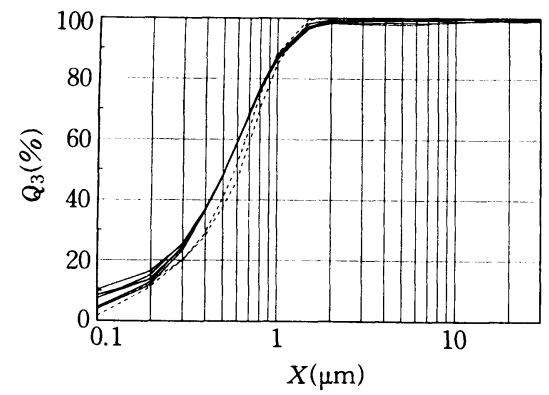

図12 WA\#10000のX線透過法による結果(2機種)

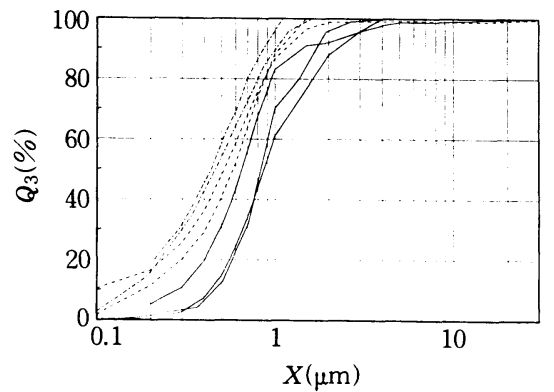

図13WA\#10000の各種沈降法(光透過法3機種: 実線, X 線法 2 機種：点線, 重量法 2 機種：一点鎖線)による結 果の比較

図13は動力学的特性のグループ(沈降法)の結果をま とめて表示した図である。粒子沈降量の経時変化を何 で測定するかによって差が見られる。注目すべきは開 発途上にある重量法(差圧法, アンバランス法)がX線 透過法に比較的よく一致していることである。

図14はレーザ一回折散乱法の結果である。7 機種14 結果が表示されている。図中の点線の結果は測定条件 からみて明らかに分散不足であると考えられる*2)。

WA\#10000のデータはグループ会の最も初期の測 定結果であるので, 装置によっては指定された共通条 件である屈折率等を入力できず，装置固定の值を使わ ざるを得ないものも含まれている*3)。したがって，同 一原理であってもこのように大きな差が結果として現 れたのには, 装置構成, 解析ソフトの違いのほか, サ ブミクロン領域が多い試料なので入力した屈折率に大 きく影響されたものと思われる。○印は後述のように

*2）この測定者の使用した超音波バスの出力および照射時間 は，共通条件通り，300W20minであったが，他の原理，試 料に対しても同様な分散不足と思われるデー夕を報告して いる。おそらく,バスの出力が定格通りに出ない状態にな つていたか，共振点を探し得なかったものと思われる。

*3）その後共通測定が進行するにしたがって, 装置, ソフト等 の改良が進み，各機種とも装置定数を自由に入力できるよ うになっていった。 


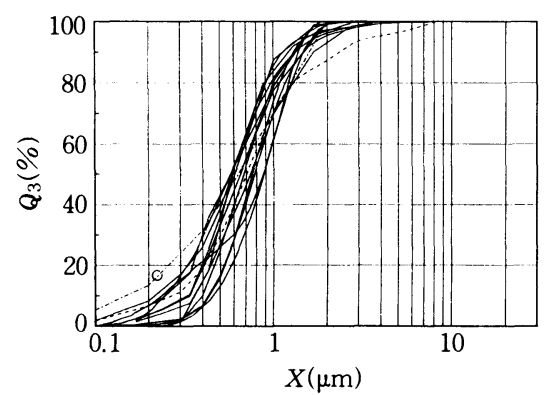

図 14 WA\#10000のレーザー回折散乱法による結果 (7 機種；14データ)

(困21参照)，この機種独特の結果である。

\section{4. $2 \mathrm{WA} \# 8000$}

図15は遮光法(実線) と電気的検知法(点線)の結果で ある。この試料の分布はほぼ，これらの装置の測定範 囲内にあると思われる。電気的検知法の再現性は極め て良い。遮光法は, 装置差および測定試料濃度による 差が現れたものと思われる。

図16は遠心沈降光透過法(点線) とX線透過法の結果 である。これを，厳密には差があるとする考え方もあ るが，WA\#10000の結果に比べれば，極めてよく一致 していると考えたほうが妥当である。これはサブミク ロン領域の粒子がほとんどないので, 吸光係数の補正

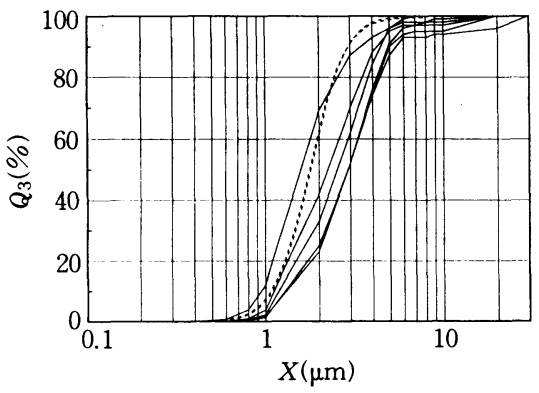

図 15 WA\#8000の電気的検知法 (点線 : 2 デー夕) と遮光法 (実線 : 6データ)による結果

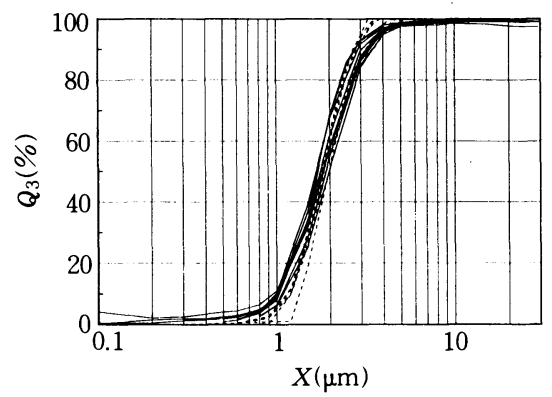

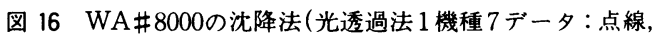
$\mathrm{X}$ 線透過法 2 機種 9 データ: 実線)による結果

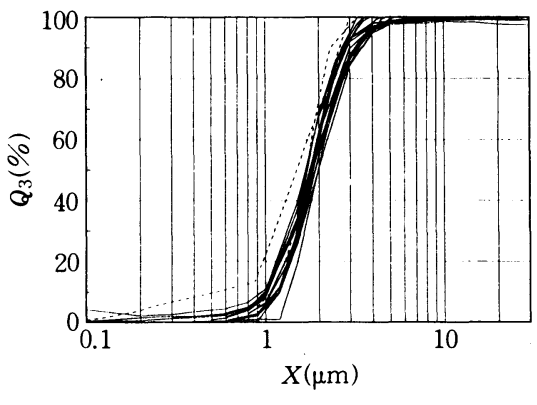

困17図16に重量法(点線)を重ねた図

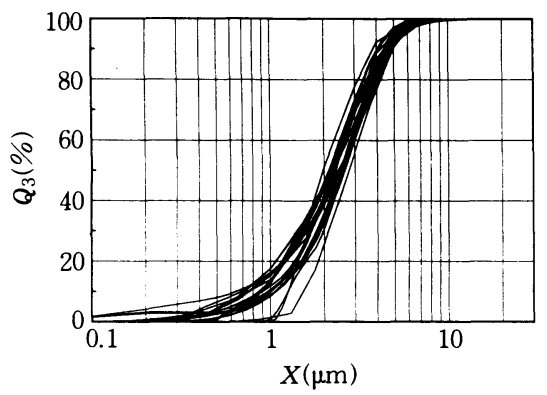

図 18 WA\#8000のレーザ一回折散乱法による結果 (7 機種 ; 26データ)

による差異が現れない試料であるためとも考えられ る。最大径, 最小径に差がでているのは装置構成と操 作状態によるものと思われる。

図17は図16に遠心沈降重量法(点線)を重ねたもので ある。光・X線光透過法の結果と比較的よく一致して おり，この方法の実用化が期待される。

図18はレーザー回折散乱法の結果である。図には7 機種26結果が記してある。図では読みとれないが，同 一機種では再現性がよい。しかし，微粒側に差が見ら れるように，機種によって多少の差が見られる。ま た，他の測定原理に較べると，有意の差が認められる ほど全体的に大きめな結果となっている。この原因に ついては不明である。

\section{4. $3 \mathrm{Fe}_{2} \mathrm{O}_{3}$ (酸化鉄 : $\alpha$-ヘマタイト)}

図19は幾何学的特性測定である, 電気的検知法 (実 線) と遮光法(点線)の結果である。測定原理間に差が あるのは，原理の違いによるものと，粒子形状の影響 によるものとの両者が考えられる。電気的検知法の結

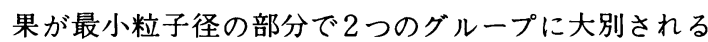
のは, 測定に用いたサンプル管の細孔径の違い $(22 \mu \mathrm{m}$

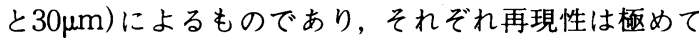
良い。遮光法は機差, 個人差が若干現れているようで ある。また，試料には遮光法および電気的検知法の測 


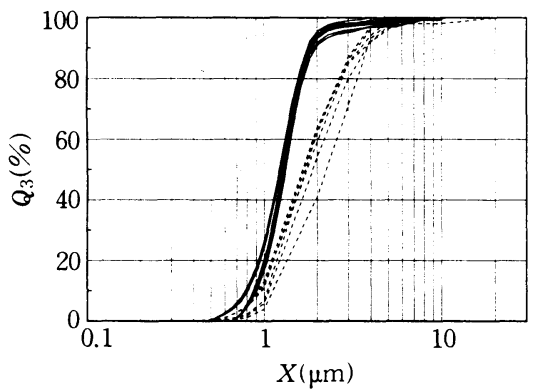

図 $19 \mathrm{Fe}_{2} \mathrm{O}_{3}$ の電気的検知法 (実線 : 21 デー夕) と遮光法 (点 線：6データ)による結果

定可能範囲以下の粒子がかなり存在していると思われ るので, 測定結果は他の測定原理に比べると分布が大 きめに観測されており，これらは参考データである。

図20は遠心沈降光透過法 (実線 ; 3 機種), X線透過法 (点線；2機種), 重量法(一点鎖線；2機種)の結果であ る。原理差, 機種差が多少見られる。

図21はレーザ一回折散乱法の結果 $(7$ 機種; 20 デ一 夕)である。かなりの差異が認められるが, 特に微粒 側に大きな差が見られる。これは，この試料がサブミ クロン領域の粒子を多少含んでいるので, 屈折率を含 めて装置定数の違いによる解析法の差が現れたのであ ろう。また，図14にも見られたように同じ機種の結果

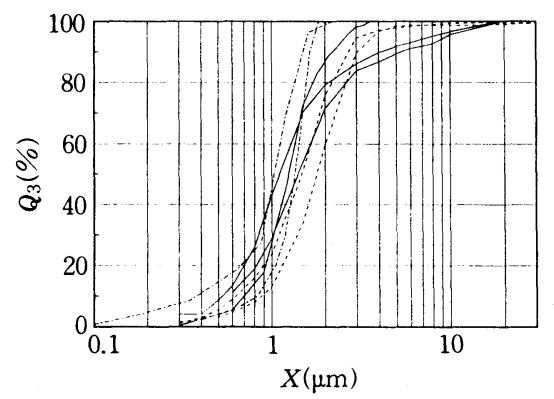

図 $20 \mathrm{Fe}_{2} \mathrm{O}_{3}$ の沈降法による結果 (光透過法 3 機種 : 実線, $\mathrm{X}$

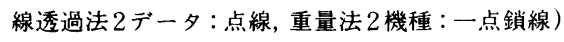

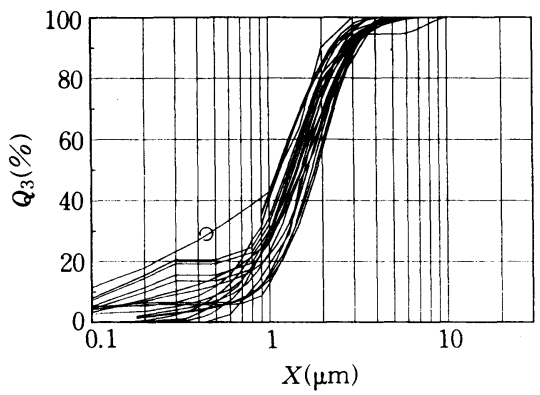

図 $21 \mathrm{Fe}_{2} \mathrm{O}_{3}$ のレーザー回折散乱法による結果 (7 機種 ; 20データ)

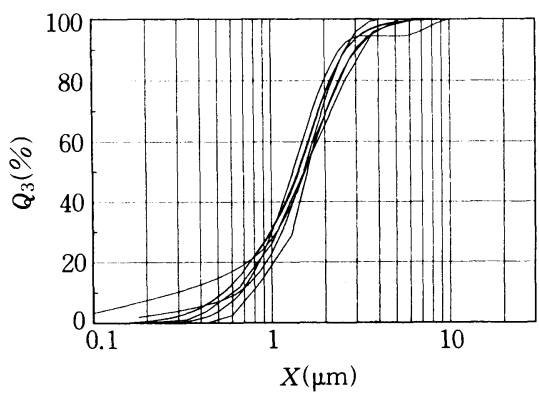

図 22 図21中のチャンピオン・データ (6 機種 $; 7$ データ)

(○印)が大きくずれているので, この機種の独特の傾 向であると思われる。

図22は前図の中からチャンピオン・データ(前述の 注)参照)を抽出して比較したものである。ただし，前 述の特異的傾向を示した装置は除いてある。また，屈 折率は各々異なっている。前困に比べると, よく一致 しているといえる。このことは,レ一ザ回折散乱法の 場合, 入力する粒子の物性值を共通にすることにはあ まり意味がなく，各機種の最適装置定数を探索しなけ ればならないことを示唆している。

\section{4. $4 \mathrm{SP} 5 \mathrm{H}$ (約0.5 $\mu \mathrm{m}$ の単分散シリカ球形粒子)}

図23は画像析法 (実線, 3 機種) と電気的検知法の結 果である。電気的検知法は測定下限が $0.52 \mu \mathrm{m}$ であっ たので参考データである。画像解析法の結果は極めて シャ一プな分布である。微粒側で多少違うのは, 画像 処理および円相当径への換算方法の違いによるものと 思われる。また, サンプル画像は同一であるが抽出粒 子数は若干異なっている。

図24は遠心沈降光透過法の結果 $(4$ 機種；6データ)で ある。実線とそれに近い方の一点鎖線のデータ(2機 種）は吸光係数の補正をしているが, 点線の 3 データ は補正していないので, 両者の違いが現れているよう である。右側の一点鎖線はラインスタート法の機種の

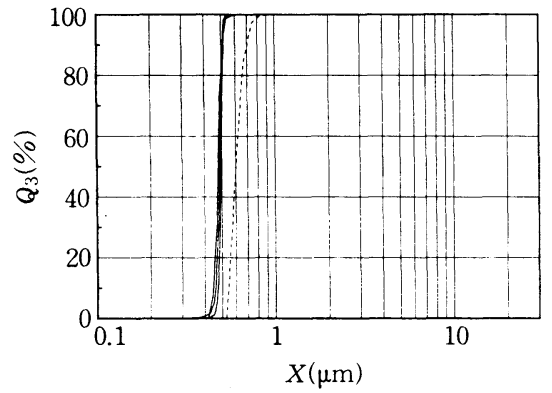

図23シリカ粒子 $(\mathrm{SP} 5 \mathrm{H})$ ) 電気的検知法 (点線: 参考デー 夕) と画像解析法 (実線 : 3 機種)による結果 


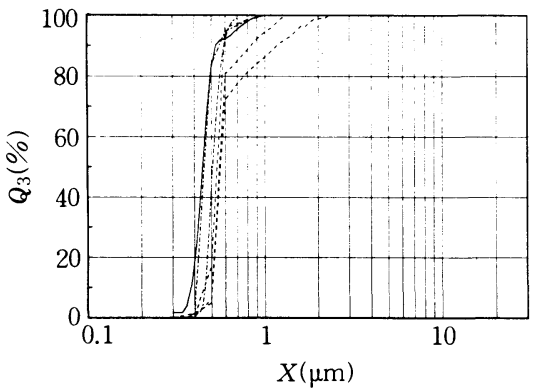

図 24 シリカ粒子(SP5H)の遠心沈降光透過法による結果 $(4$ 機種 : 6 データ)

結果である。点線は 1 機種 3 データであるが, 右から 2 本は回転数が順番に $3000,5000 \mathrm{rpm}$ である。回転数 が小さいほど，遠心希釈効果(「粒子径計測技術」第 4 , 5 章参照)が大きく現れ，無いはずの大粒子が存在して いるかような結果となっている。もう 1 本の点線は5000 rpmのデータの遠心希釈効果を補正した結果である。 無いはずの大粒子の存在が見事に補正されている。幅 広い分布をもつ試料の場合は，遠心希釈効果の影響は さほど目立たないようであるが，この試料のようにシ ヤープな分布の場合は無視できないほど極端に現れる ので補正が必要となる。

図25はX線透過法の結果である。実線は同じ機種 (自然沈降)であるが測定者(装置)が異なる。粗粒側に 大きく尾を引いているのは試料の分散が悪かったため と考えられる。点線は遠心沈降の機種の結果である。 この段階からX線透過法にも遠心沈降モードの機種が 参画してきた。

图26はすべての沈降法の結果をプロットしたもので ある。一点鎖線が重量法である。一番右の分散の悪い 結果を除いても, 沈降量のディテクトの仕方(測定物 理量), 補正方法によりかなりの差が見られる。

図27はレーザ回折散乱法(実線, 5機種；7デー夕) と 光子相関法(点線)の結果である。シャープなもの, ブ

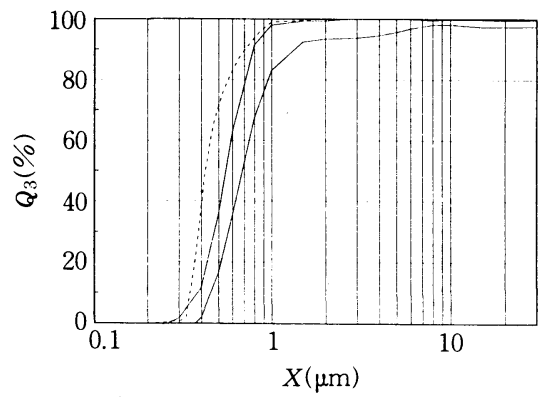

図 25 シリカ粒子(SP5H)のX線透過法による結果 (2機種: 3 デー夕)

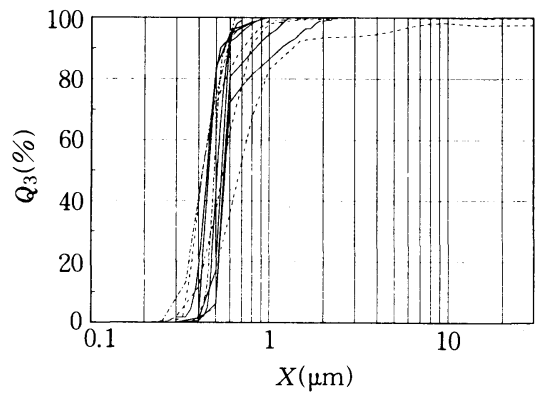

図 26

シリカ粒子 $(\mathrm{SP} 5 \mathrm{H})$ の各種沈降法による結果(光透過 法: 実線, X線透過法：点線, 重量法：一点鎖線）

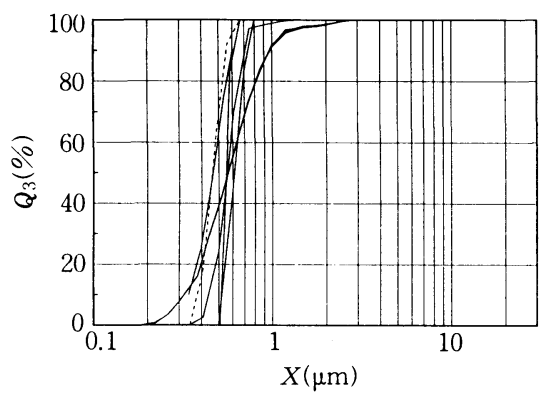

図 27 シリカ粒子(SP5H)のレーザ一回折散乱法(実線: 5 機種 7 データ) と光子相関法(点線)による結果

ロードなもの等, 機種によりかなりの差が見られる。 光子相関法(点線)がシャープでしかも $0.5 \mu \mathrm{m}$ に近いモ 一ド径を得ており，この方法がサブミクロン以下の単 分散試料に強いことを伺わせている。今回のグループ 会では, 粒子相関法のデー夕はあまり蓄積できなかっ たが,この方法は今後サブサブミクロンの試料測定に 多用されると予測されるので, この方法に関する詳細 な検討をどの時点かで行っておく必要があるであろ j。

\section{4. $5 \mathrm{SP} 9 \mathrm{H}($ 約 $0.9 \mu \mathrm{m}$ の単分散シリカ球形粒子)}

図28は画像析法の結果 $(3$ 機種; 3 デー夕) と電気的検 知法の結果 $(1$ デー夕)に遮光法をともにプロットした ものである。どれも幾何学的特性を測定しているので あるが，遮光法はブロードな分布で小さめな結果とな つている。電気的検知法の測定可能範囲は試料の分布 をほほカガーしていると思われる。したがって, 画像 解析法と比較的良い一致を示しているが, 大きめに尾 を引いているのは, 粒子が細孔の中心を通過しない現 象(壁面近傍通過効果)の結果であると思われる。これ は細孔断面の電界強度は場所によって一様ではなく, 壁面近くの電界強度が中心に比べるとやや大きいの で，粒子が壁面近傍を通過した場合，大きめの粒子と して観測されてしまう現象である(詳細は「粒子径計 


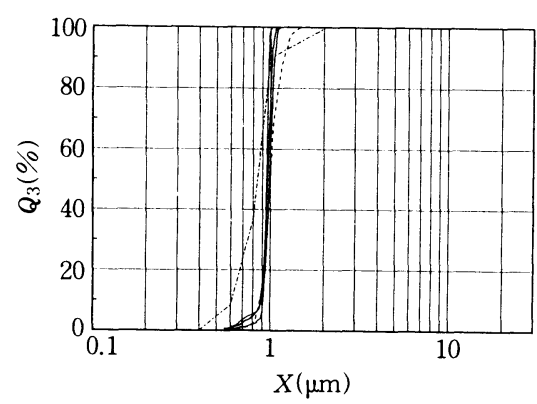

図 28 シリカ粒子(SP9H)の電気的検知法(点線) と画像解 析法 (実線: 3 機種)による結果に遮光法 (一点鎖線)の 結果を重ねた図

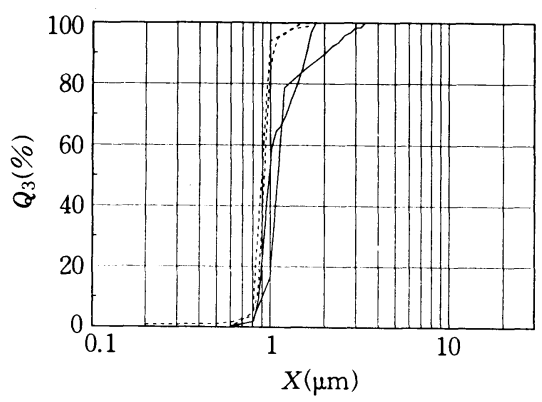

図 29 シリカ粒子(SP9H)の遠心沈降光透過法による結果 (4 機種)

測技術」第11章参照 $)^{3)}$ 。

図29は遠心沈降光透過法 4 機種 $(4$ データ)の結果で ある。実線は遠心希釈効果を補正していない2 機種で ある。点線のうち1本は遠心希釈効果の補正を行った 機種, 他はラインスタート法の機種による結果であ り，比較的よく一致している。ラインスタート(一斉 沈降)法とは試料粒子をある沈降夜表面に保持してお き, 時間 $\mathrm{t}=0$ で一斉に遠心沈降させる方法である。し たがって, 同一測定面で粒子濃度の経時変化を観測し ている限り,どの大きさの粒子も沈降距離が同じであ るから遠心希釈効果は全く同じになるので補正の必要 がない。したがって，点線 2 本が比較的良く一致した のであろう。

図30はX線透過法 $(3$ 機種；7デー夕)の結果である。 実線 $(4$ 本) は同一機種で異なる測定者(装置)の結果で あるがそそのうち 1 本がかなり大きめにでている。こ れは試料分散用の超音波の出力が75Wであったため 分散不足である。点線 $(2$ データ)は同一測定者が行っ た結果であるが, 分散は超音波バスとホモジナイザー によるものである。大きめにでているデー夕は指定通 り300Wの超音波バス10分の分散を実施しているが分 散不足の結果となった。この測定者の他の共通試料の

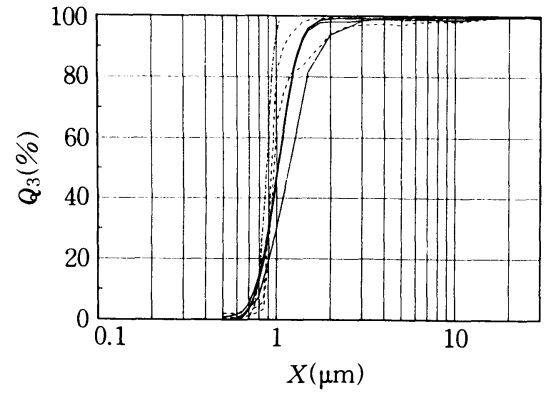

図 30 シリカ粒子(SP9H)のX線透過法による結果 (3機種 : 7データ)

場合も同様に分散不足気味であった(WA\#10000の節 の脚注参照)。一点鎖線は遠心沈降モ一ドの機種であ る。小さめではあるが画像解析法の結果(図28)に似た ような，かなりシャープな分布を得ている。

図31は沈降法の結果の比較である。一点鎖線は重量 法の結果である。分散不足, 遠心希釈効果未補正のデ 一夕を除くとかなり良い一致を示している。

図32はレーザ回折散乱法(10機種；11データ) と光子 相関法(一点鎖線；1データ)の結果である。点線は試 料分散に用いた超音波バスの出力が指定以下 $(25 \sim 41$ W)であったので明らかに分散不足である。機種によ

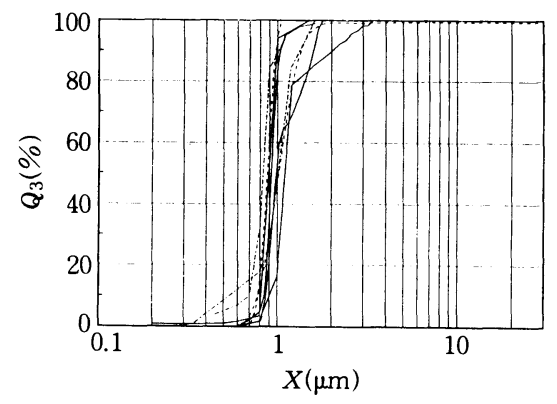

図 31 シリカ粒子(SP9H)の各種沈降法による結果 (光透過 法: 実線, X線透過法：点線, 重量法：一点鎖線）

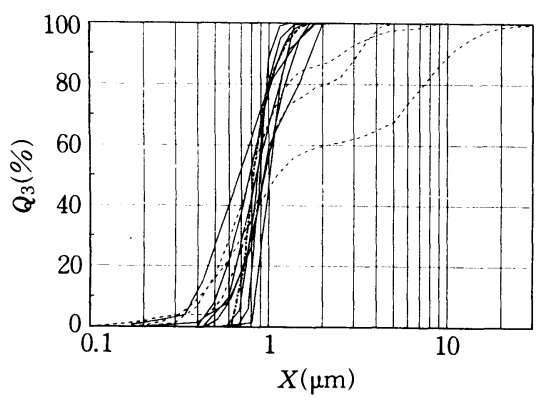

図 32 シリカ粒子(SP9H)のレーザー回折散乱法(実線およ び点線 : 10 機種11データ) と光子相関法(一点鎖線 : 1 データ)による結果 
ってシャープにでるものからブロードにでるものまで かなりの差が見られる。入力した届折率は装置固有の ものから，指定值まで種々である。全体的に言えるこ とは屈折率を実測値ないし文献值で揃えても結果は機 種によってかなりの差がある。これは実測値ないし文 献值が各装置に対して最適值ではなく, デー夕の解析 結果に影響を与える装置固有定数があるものと思われ る。その中で, 光子相関法の結果 (一点鎖線) が各装置 間のばらつきの中間的位置にシャープな分布として得 られていることは注目に値する。光子相関法はやはり 単分散に強いのであろう。

\section{4. $6 \mathrm{SP} 14 \mathrm{H}$ (約1.4 $\mu \mathrm{m}$ の単分散シリカ球形粒子)}

図33は画像解析法 (実線, 3 機種; 3 デー夕) と電気的 検知法 (点線)による結果に遮光法 (一点鎖線)を重ねた ものである。電気的検知法, 遮光法とも測定範囲は試 料粒子の粒子径分布をカバーしている。遮光法は他に 比較してブロードである。電気的検知法は壁面近傍通 過効果のためか, 大きめの粒子があるかのような測定 結果になっている。

図34は遠心沈降光透過法の結果 (5機種; 8データ) である。やはり, 遠心沈降希䣋効果が補正されていな い機種の結果は粗くなっている。点線はラインスター

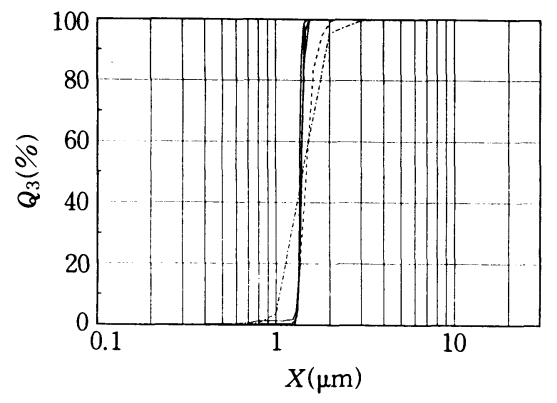

図 33 シリカ粒子 $(\mathrm{SP} 14 \mathrm{H})$ の遮光法 (一点鎖線), 電気的検 知法(点線) と画像解析法 (実線 $: 3$ 機種)による結果 の比較

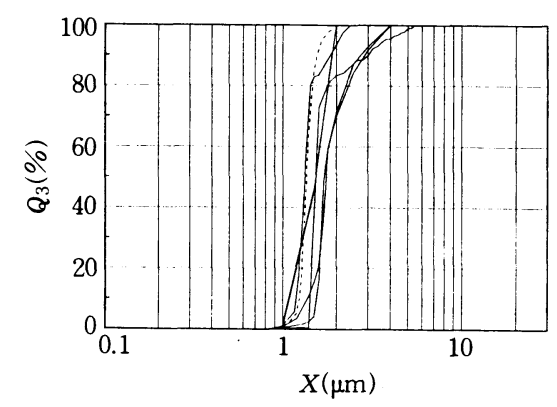

図 34 シリカ粒子 $(\mathrm{SP} 14 \mathrm{H})$ の遠心沈降光透過法による結果 (5機種 : 8データ)
ト法の結果である。図33の画像解析法の結果に近い極 めてシャープな分布として観測されている。

図35はX線透過法の結果 (2 機種 ; 5 デー夕)である。 自然沈降法(実線)はブロードな結果を示している。遠 心沈降モードの機種(点線)の結果はシャープな分布で あり前図の点線とほぼ一致しているが,これらは同じ メーカーの機種である。同一メーカーが異なる原理の 機種を市販している場合, 両者の測定結果が異なるこ とが多々あるので，この結果は注目すべきことであ る。

図36は沈降法すべての比較である。一点鎖線は重量

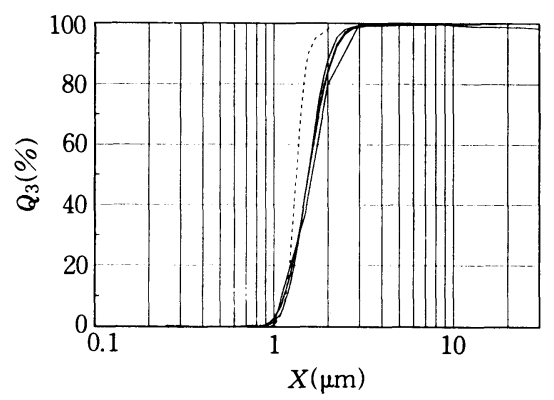

図 35 シリカ粒子(SP14H)のX線透過法による結果 (2 機種 $; 5$ データ)

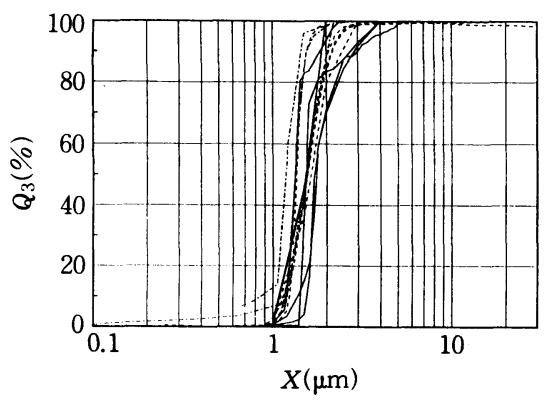

图 36 シリカ粒子(SP14H)の各種沈降法による結果 (一点鎖線は重量法)

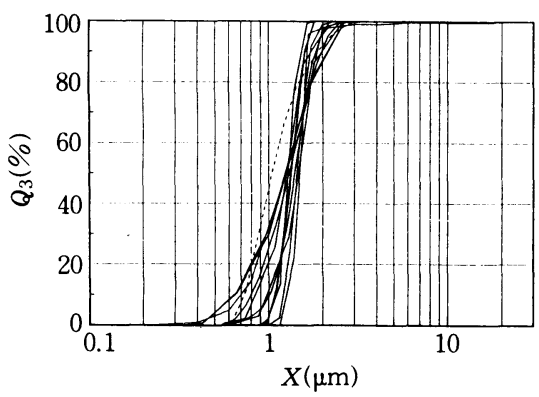

図 37 シリカ粒子(SP14H) のレーザー回折散乱法(実線 : 9 機種 12 デー夕) と光子相関法 (点線 : 1 データ)による 結果 
法である。やはり，測定物理量によってかなり差が見 られる。

図37はレーザー回折散乱法(9機種；12データ) と光 子相関法 (点線, 1 機種)の結果である。レーザ一回折 散乱法の結果は他のシリ力粒子試料と同様, かなりの 差が見られる。光子相関法は小さめに観測している。 やはり, 粒子相関法の測定上限は $1 \mu \mathrm{m}$ 程度であろう か。

\section{5. あとがき} の要因により，原理間・機種間・装置間の整合性は必 ずしも良いとは言えない結果となった。その原因につ いては紙面の都合上, 本稿では十分に検討しきれてい ない。詳細な検討は, 各測定原理 ·装置の特徵を熟知 された娈者の独自の検討にゆだねることにする。

いずれにしても，これからも装置は進化し，操作の 自動化・簡便化, デー夕処理の自動化はますます進む であろう。それによって, 測定者の熟練度もさほど必 要でなくなり, 鿁差を生ずる要因も大幅に削減されて いくことは間違いない。しかし，そのために測定から
以上, 共通試料の共同測定結果を紹介したが, 種々

データ処理までのプロセスのブラックボックス化が進 みアンノーンな部分がますます增えるであろうから， いったい何が測られているのか分らないまま, データ が一人歩きをしてしまう危険性が增してくるであろう ことも否めない。おかしなデータの一人歩きを阻止す るために，ユーザーとしてはますます賢さが求めら れ，所有する装置の原理や特徵を熟知しておくことが 必要となるであろう。塆者各位がそれぞれの測定装置 の特徵を生かし，目的にあった正しい測定と評価をお こなうために本グループ会の成果がいささかでもお役 にたてれば幸いである。

終わりに，本報告の核となった貴重な成果を得るた めに，共同測定，データの検討等に熱心に参加してく ださった粉体工学会サブミクロン粒度測定グループ会 のメンバーの皆さんに深甚の謝意を表する次第であ る。また, 共通試料に用いた単分散シリカ粒子は(株) トクヤマ化学技術研究所から特別に調製提供していた だいた。また, 粒子の屈折率测定は京都フィショント ラック社にご尽力いただいた。合わせてここに謝意を 表します。

\section{参 考 文 献}

1）粉体工学会編：「粒度測定技術」, pp.323 339, 日刊工 業新聞社 (1975)

2）粉体工学会：粒度測定セミナーテキスト「最近の粒度
分布測定法の総合的比較検討」, 1987年(東京)

3）粉体工学会編「粒子径計測技術」, pp.199 214 日刊工 業新聞社 (1994)

\section{古々唁簐}

\section{Eulerian- Lagrangian Method}

日本語に直訳すれば，オイラー・ラグランジュ法にな るが、まだそれほど一般的ではない。この言葉は，混相 流の数值解析に登場する。流体力学をはじめて勉強する 時, 流体の運動の記述には 2 種類の方法があると習うは ずである。つまり 1 つは流体の微小部分を粒子と見な し，この流体粒子を時間の関数として追跡する方法で, これはラグランジュの方法と呼ばれる。ここでいう粒子 は流体を構成する分子ではない。
他の 1 つは，流体粒子という概念を用いずに，流体が 空間に連続的に分布している物質であることから運動を 空間座標の関数として記述する方法である。こちらは通 常, オイラーの方法と呼ばれる。オイラーの方法であっ ても非定常な運動に対してはさらに時間が独立変数とし て関与する。普通, 流体力学ではオイラーの方法が一般 的である。なせ混相流にこの言葉が出てきたかといえ ば, 混相流の数値解析法の一つとして, 流体中の個々の 粒子（固体, 気泡, 液滴) に関しては時間の関数として 計算し、流体運動に関しては通常の流体力学の通りにオ イラーの方法で解く方法が使われるようになったから である。このような方法に対して表題の「EulerianLagrangian Method」という呼ひ名が与えられてい る。流体中の個々の粒子を時間の関数として計算するの は当たり前のようであるが，それまでは，粒子の集合体 を一つの連続体と見なす方法がより一般的であった。

(千里荷馬) 